\title{
Stereoactive lone pair of electrons on bismuth(III): tris(3-hydroxy- 2-methyl-4H-pyran-4-onato)bismuth(III)
}

\author{
Boris G. Sukhov, ${ }^{\mathrm{a}}$ Svetlana A. Mukha, ${ }^{\mathrm{a}}$ Irina A. Antipova, ${ }^{\mathrm{a}}$ Svetlana A. Medvedeva,

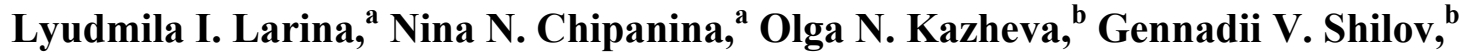 \\ Oleg A. Dyachenko, ${ }^{b}$ and Boris A. Trofimov ${ }^{a}$ \\ ${ }^{a}$ A. E. Favorsky Irkutsk Institute of Chemistry, Siberian Branch of the Russian Academy of \\ Sciences, 664033 Irkutsk, Russian Federation \\ ${ }^{b}$ Institute of Problems of Chemical Physics of the Russian Academy of Sciences, 142432 \\ Chernogolovka, Russian Federation \\ E-mail: svetlanamukha@irioch.irk.ru
}

This manuscript is dedicated to Dr. Arlette Solladié-Cavallo on the occasion of her 70th anniversary

\begin{abstract}
Another rare example of stereoactive lone pair of electrons on six-coordinated bismuth(III) previously unknown tris(3-hydroxy-2-methyl-4H-pyran-4-onato)bismuth(III) has been synthesized and characterized by spectral methods (IR, UV, ${ }^{1} \mathrm{H}$ NMR, ${ }^{13} \mathrm{C}$ NMR) and singlecrystal X-ray studies. The complex crystallizes in the monoclinic space group $P 2_{1} / n ; a=$ 10.495(2), $b=16.240(3), c=10.788(2) \AA, \beta=91.47(3)^{\circ}, V=1838.1(6) \AA^{3}, Z=4, \lambda=0.71073$ $\AA$. Conformation of the molecule looks like a butterfly. Atom of the metal has six-coordinated environment and coordination polyhedron as distorted pentagonal pyramid. Molecules of complexes are formed the dimer associates in the crystal packing due to shorten $\mathrm{Bi}$... $\mathrm{Bi}$ and Bi...O bonding interactions.
\end{abstract}

Keywords: Maltol, bismuth(III), NMR spectroscopy, X-ray diffraction, stereoactive lone pair

\section{Introduction}

Currently 3-hydroxy-2-methyl-4H-pyran-4-one (maltol), an non-toxic ( $\left.\mathrm{LD}_{50} 1400 \mathrm{mg} / \mathrm{kg}\right)^{1}$ chelating ligand of natural ${ }^{2-5}$ origin, attracts an ever-increasing interest. This fact is explained by the possible applications of maltol to control the level of metals content in an organism, either by excretion of their excess in the form of metal chelates, through coordination with maltol in the 
organism, ${ }^{6-8}$ or by transportation of necessary metals as chelate complexes to the organism with therapeutic ${ }^{9,10}$ and diagnostic purposes. ${ }^{11-13}$

Inorganic compounds of bismuth (trioxide, nitrate) or bismuth acetate are usually used for the treatment of various gastrointestinal diseases as well as the preparation of antiseptic and woundhealing products. ${ }^{14,15}$ But these drugs possess various side-effects (bismuth stomatitis, dermatitis, nephropathy) related to their toxicity and slow and incomplete excretion from organism. ${ }^{15}$ As a result, bismuth complexes prepared on the basis of natural non-toxic maltol, showing antibacterial ${ }^{1}$ and antioxidant ${ }^{16-18}$ properties may be of special medicinal interest. Thus, the detailed information on structure of maltol-based complexes of bismuth is gaining in importance. This information may also hold a fundamental stereochemical aspect: the stereoactive lone pair on bismuth(III). To the best of our knowledge, only a few compounds of six-coordinated bismuth(III) having a stereochemically active lone pair of electrons (stereoactive lone pair) have been reported, ${ }^{19-21}$ while the overwhelming majority of bismuth compounds have no such lone pair. $^{21,22}$

\section{Results and Discussion}

Tris(3-hydroxy-2-methyl-4H-pyran-4-onato)bismuth(III) was prepared by the reaction of maltol with bismuth nitrate pentahydrate. It is known that the ion-coordinative chelatation of maltol is favored by its ionization at the $\mathrm{O}-\mathrm{H}$ bond to form one-charge maltolate-anion $\mathrm{C}_{6} \mathrm{H}_{5} \mathrm{O}_{3}{ }^{-}$(L). ${ }^{23}$ Therefore, the reaction was carried out in the presence of alkali $(2 \mathrm{~N} \mathrm{NaOH})$, which leads to maltol ionization $\left(\mathrm{pK}_{\mathrm{a}}\right.$ in water 8.6). At the same time the reaction equilibrium was shifted towards the formation of target chelate complex due to the neutralization of acid released during the reaction (Scheme 1).

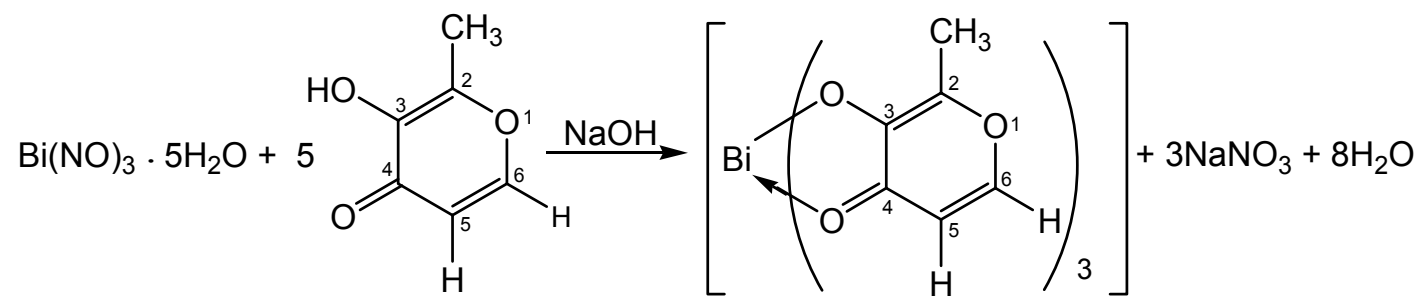

\section{Scheme 1}

According to the elemental analysis data the complex of maltol with bismuth(III) has a stoichiometric ratio metal : ligand of $1: 3$.

In the UV spectrum of the tris(3-hydroxy-2-methyl-4H-pyran-4-onato)bismuth(III) (Fig. 1 (b)) in addition to the band at $270 \mathrm{~nm}$ (caused partial complex dissociation in the protonodonor solvent resulting to free maltol) appears the band at $312 \mathrm{~nm}$ provided $\pi \rightarrow \pi^{*}$ transition of maltol at anion bonded with $\mathrm{Bi}^{3+}$. That confirmed the position coincidence of observed absorption 
maxima at 270 and $312 \mathrm{~nm}$ with those of initial maltol (Figure 1a) and maltol in alkaline buffer (Fig. 1 (c)) (where it is present mainly as anion), ${ }^{23,24}$ respectively. Decrease in the excitation energy is caused by the shift of $\pi$-electrons across the conjugated chain (polarization) under maltol ionization with formation of the chelate. The bands of charge-transfer (metal-ligand) and $\mathrm{d} \rightarrow \mathrm{d}^{*}$ transitions, apparently, have low intensity or these transitions are spin forbidden. Since, they are not registered even at increase of concentration and light way. Besides the position of an observable absorption band at $312 \mathrm{~nm}$ does not depend on an electronic configuration of maltol complexes, ${ }^{24}$ therefore it can not be referred to $\mathrm{d} \rightarrow \mathrm{d}^{*}$ transitions or to the charge-transfer band.

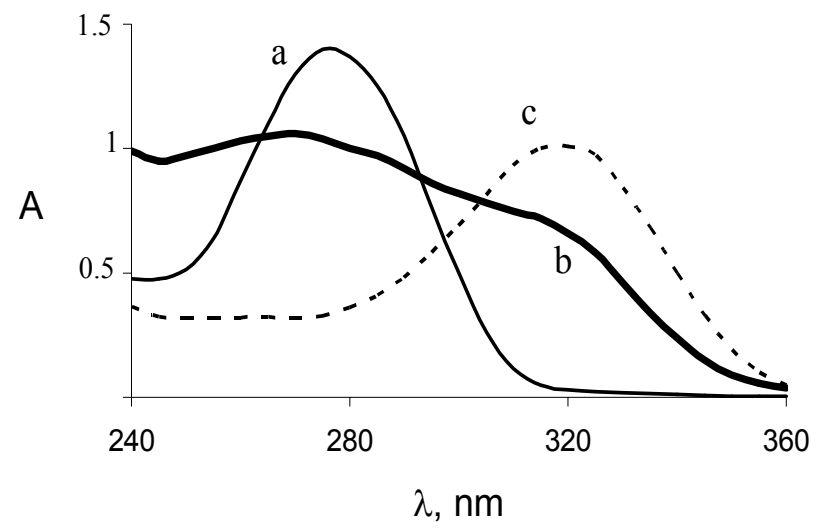

Figure 1. UV spectrum $\left(c=5 \times 10^{-5} \mathrm{M}, \mathrm{MeOH}\right)$ : (a) maltol $\left(\varepsilon_{\max } 28000\right)$, (b) tris(3-hydroxy-2methyl-4H-pyran-4-onato)bismuth(III) $\left(\varepsilon_{\max } 21200,15000\right)$ and (c) maltol $\left(\mathrm{pH}=10, c=6.87 \times 10^{-5}\right.$ M, $\varepsilon_{\max }$ 14702).

The fact that maltol is bound with metal ion through the oxygen atom of carbonyl group is confirmed by a significant decrease (by $50 \mathrm{~cm}^{-1}$ ) of valence vibration frequency $v(C=O)$ in IR spectrum of the complex as compared to the spectrum of free lignand (Table 1). ${ }^{25}$ Disappearance of the absorption band $v(\mathrm{O}-\mathrm{H})$ at $3240 \mathrm{~cm}^{-1}$, assigned to maltol hydroxyl, is indicative of the hydroxyl group deprotonation and its coordination with respect to bismuth. The appearance of the bands at $445 \mathrm{~cm}^{-1}$ and $251 \mathrm{~cm}^{-1}$ proves the availability of the metal-oxygen bond. ${ }^{26,27,28}$ Redistribution of electron density in the chelate results in shift of absorption bands, which correspond to conjugated double bonds of $\gamma$-pyrone, toward low-frequency (Table 1). ${ }^{25}$ 
Table 1. Characteristic frequencies $\left(v, \mathrm{~cm}^{-1}\right)$ in IR spectra of maltol and tris(3-hydroxy-2methyl-4H-pyran-4-onato)bismuth(III) in $\mathrm{KBr}$ and vaseline oil

\begin{tabular}{llllll}
\hline & \multicolumn{5}{c}{ Assignment } \\
\cline { 2 - 6 } Compound & $v \mathrm{O}-\mathrm{H}$ & $\delta \mathrm{O}-\mathrm{H}$ & $v \mathrm{C}=\mathrm{O}$ & $v \mathrm{C}=\mathrm{C}$ & $v \mathrm{M}-\mathrm{O}$ \\
& \multirow{2}{*}{3240} & 1660 & 1625 & 1565 & \\
\hline $\mathrm{HL}$ & & & 1575 & 1608 & 445 \\
$\mathrm{BiL}_{3}$ & & & 1508 & 251 \\
& & & & & \\
\hline
\end{tabular}

${ }^{1} \mathrm{H}$ NMR spectra of maltol and its bismuth complex (Table 2) provide support for the involvement of $\mathrm{OH}$-group proton in the reaction: the spectrum of its metal derivative show no wide resonant signal at $7.31 \mathrm{ppm}$, caused by hydroxyl proton. In addition, the resonance signal of $\mathrm{H}_{5}, \mathrm{H}_{6}$ and $\mathrm{CH}_{3}$-group protons are shifted with respect their position in maltol that also point to the redistribution of electron density in new metal chelate molecule. So, the signals of $\mathrm{H}_{5}$ and $\mathrm{H}_{6}$ protons are shifted towards high field, while signal of the $\mathrm{CH}_{3}$-group protons - towards low field. Signals of $\mathrm{H}_{5}$ and $\mathrm{H}_{6}$ protons of both maltol and its complex are observed as doublets.

To assign the carbon signals the ${ }^{13} \mathrm{C}$ NMR spectra (without decoupling from protons) and twodimensional (2D) $\mathrm{HMBC}{ }^{1} \mathrm{H}-{ }^{13} \mathrm{C}$ spectra were recorded (Table 2). As is seen from the table the values of coupling constants ${ }^{1} J_{\mathrm{CH}}$ of $\mathrm{C}_{6}$ atom are higher than those of $\mathrm{C}_{5}$ atom that can be explained by neighborhood of the $\mathrm{C}_{6}$ atom with oxygen atom.

Comparative analysis of ${ }^{13} \mathrm{C}$ NMR spectra of maltol and its bismuth complex (Table 2) also proves the formation of chelate compound. So, resonance signals of carbon atoms located near to the coordination center $\left(\mathrm{C}_{2}, \mathrm{C}_{3}, \mathrm{C}_{4}, \mathrm{C}_{5}\right)$ are shifted towards lower field. The complex formation seems to be accompanied by the partial deshielding of the ligand carbon atoms that leads to the signals shift observed. The resonance signal of the $\mathrm{C}_{6}$ atom is shifted (like the signal of the $\mathrm{H}_{6}$ atom in ${ }^{1} \mathrm{H}$ NMR spectrum) towards higher field. This effect can be explained by the decrease of conjugation in the $\gamma$-pyrone ring.

Crystal structure of the complex is formed by one crystallographic independent molecule $\mathrm{C}_{18} \mathrm{H}_{15} \mathrm{BiO}_{9}$ (Fig. 2), taking general position in the unit cell. The conformation of the molecule looks like a butterfly: the heterocycles with $\mathrm{O} 1, \mathrm{O} 2, \mathrm{O} 6$ and $\mathrm{O} 7$ atoms - «wings», are planar. The dihedral angle formed by $\mathrm{BiO} 1 \mathrm{C} 1 \mathrm{C} 2 \mathrm{O} 2$ and $\mathrm{BiO} 6 \mathrm{C} 15 \mathrm{C} 16 \mathrm{O} 7$ planes is $157.7^{\circ}$. The perpendicular $\mathrm{BiO} 3 \mathrm{C} 8 \mathrm{C} 9 \mathrm{O} 4$ plane is the «body of the butterfly». The dihedral angles between this plane and «wings» are 68.9 and $90.7^{\circ}$, for $\mathrm{BiO} 1 \mathrm{C} 1 \mathrm{C} 2 \mathrm{O} 2$ and $\mathrm{BiO} 6 \mathrm{C} 15 \mathrm{C} 16 \mathrm{O} 7$ planes, respectively. 
Table 2.The values of ${ }^{1} \mathrm{H}$ and ${ }^{13} \mathrm{C}$ NMR $(\delta$, ppm) chemical shifts and coupling constants $(J, \mathrm{~Hz})$ of maltol and tris(3-hydroxy-2-methyl-4H-pyran-4-onato)bismuth(III)

\begin{tabular}{|c|c|c|c|c|c|c|c|}
\hline \multirow[b]{2}{*}{ Compound } & \multicolumn{7}{|c|}{${ }^{1} \mathrm{H}$ NMR } \\
\hline & & & & $\mathrm{H}_{5}$ & $\mathrm{H}_{6}$ & $\mathrm{CH}_{3}$ & $\mathrm{OH}$ \\
\hline \multirow[t]{2}{*}{ HL } & & & & 6.42 & 7.70 & 2.36 & 7.31 \\
\hline & & & & ${ }^{3} J_{5,6}=5.2$ & ${ }^{3} J_{5,6}=5.2$ & & \\
\hline \multirow[t]{2}{*}{$\mathrm{BiL}_{3}$} & & & & 6.41 & 7.64 & 2.42 & \\
\hline & & & & ${ }^{3} J_{5,6}=5.1$ & ${ }^{3} J_{5,6}=5.1$ & & \\
\hline \multicolumn{8}{|c|}{${ }^{13} \mathrm{C}$ NMR } \\
\hline \multirow{4}{*}{ HL } & $\mathrm{C}_{2}$ & $\mathrm{C}_{3}$ & $\mathrm{C}_{4}$ & $\mathrm{C}_{5}$ & $\mathrm{C}_{6}$ & $\mathrm{CH}_{3}$ & \\
\hline & 149.51 & 143.44 & 173.25 & 113.35 & 154.22 & 14.37 & \\
\hline & ${ }^{2} J_{\mathrm{CH}}=7.4$ & ${ }^{2} J_{\mathrm{CH}}=2.8$ & ${ }^{2} J_{\mathrm{CH}}=7.4$ & ${ }^{1} J_{\mathrm{CH}}=167.9$ & ${ }^{1} J_{\mathrm{CH}}=199.7$ & ${ }^{1} J_{\mathrm{CH}}=129.6$ & \\
\hline & & & ${ }^{3} J_{\mathrm{CH}}=1.2$ & ${ }^{2} J_{\mathrm{CH}}=8.5$ & ${ }^{2} J_{\mathrm{CH}}=6.4$ & & \\
\hline \multirow[t]{3}{*}{$\mathrm{BiL}_{3}$} & 157.42 & 153.88 & 179.83 & 115.22 & 152.12 & 15.05 & \\
\hline & & & ${ }^{2} J_{\mathrm{CH}}=7.4$ & ${ }^{1} J_{\mathrm{CH}}=168.0$ & ${ }^{1} J_{\mathrm{CH}}=196.8$ & ${ }^{1} J_{\mathrm{CH}}=129.3$ & \\
\hline & & & ${ }^{3} J_{\mathrm{CH}}=2.0$ & ${ }^{2} J_{\mathrm{CH}}=9.0$ & ${ }^{2} J_{\mathrm{CH}}=6.0$ & ${ }^{3} J_{\mathrm{CH}}=5.4$ & \\
\hline
\end{tabular}

The metal atom is hexa-coordinated in a distorted pentagonal pyramid. The $\mathrm{O} 3$ atom is located on the vertex of the pyramid, while O1, O2, O4, O7 and $\mathrm{O} 6$ atoms are placed at base of the pyramid. These atoms form distorted pentagon with bismuth atom in the center. Unlike the known octahedral maltolate complexes of six-coordinated $\mathrm{Al}^{\mathrm{III}},{ }^{29} \mathrm{Fe}^{\mathrm{III}}{ }^{30}$ and thiomaltol complex of six-coordinated $\mathrm{Fe}^{\mathrm{III}},{ }^{31}$ the formation of distorted pentagonal pyramid of six-coordinated $\mathrm{Bi}^{\mathrm{III}}$ is determined by the presence of stereoactive lone pair. ${ }^{32-34}$ This is another rare example of such bismuth compounds. ${ }^{19-21}$

Important bond distances and bond angles for complex appear in Table 4 and 5. The distances $\mathrm{Bi}-\mathrm{O}$ are unequal - the $\mathrm{Bi}-\mathrm{O} 2, \mathrm{Bi}-\mathrm{O} 4$ and $\mathrm{Bi}-\mathrm{O} 7$ bonds are longer (2.481(4), 2.487(3), 2.447(4) $\AA$, respectively) than the $\mathrm{Bi}-\mathrm{O} 1, \mathrm{Bi}-\mathrm{O} 3$ and $\mathrm{Bi}-\mathrm{O} 6$ bonds (2.276(3), 2.150(3), 2.275(3) $\AA$, correspondingly) that is indicative of coordination nature of the $\mathrm{Bi}-\mathrm{O} 2$, $\mathrm{Bi}-\mathrm{O} 4$ and $\mathrm{Bi}-\mathrm{O} 7$ bonds and covalence nature of the $\mathrm{Bi}-\mathrm{O} 1, \mathrm{Bi}-\mathrm{O} 3$ and $\mathrm{Bi}-\mathrm{O} 6$ bonds. Extension of the $\mathrm{Bi}-\mathrm{O} 1$ and $\mathrm{Bi}-\mathrm{O} 6$ bonds in comparison with the $\mathrm{Bi}-\mathrm{O} 3$ bond is probably related to participation of the $\mathrm{O} 1$ and $\mathrm{O} 6$ atoms in shorten intermolecular interactions $\mathrm{Bi}$... $\mathrm{O} 1$ and Bi...O6 with the distances of 3.140(3) and 3.105(3) $\AA$, respectively (sum of van der Waals radii of the corresponding atoms is $3.9 \AA) .{ }^{35}$ In addition, shorten interaction $\mathrm{Bi}$... Bi having the distance of $3.721(1) \AA$ was found (sum of van der Waals radii is $4.8 \AA$ ). ${ }^{35}$ 
Table 3. The basic crystallographic data of X-ray diffraction study tris(3-hydroxy-2-methyl-4Hpyran-4-onato)bismuth(III)

\begin{tabular}{cc}
\hline Parameters & \\
\hline Formula & $\mathrm{C}_{18} \mathrm{H}_{15} \mathrm{BiO}_{9}$ \\
Molecular weight & 584.28 \\
Syngony & Monoclinic \\
Space group & $\mathrm{P} 2_{1} / \mathrm{n}$ \\
Parameters of elementary cell & \\
$a / \AA$ & $10,495(2)$ \\
$b / \AA$ & $16,240(3)$ \\
$c / \AA$ & $10,788(2)$ \\
$\alpha /{ }^{\circ}$ & 90 \\
$\beta /{ }^{\circ}$ & $91,47(3)$ \\
$\gamma^{\circ}$ & 90 \\
$U / \AA^{3}$ & $1838,1(6)$ \\
$\mathrm{Z}$ & 4 \\
$\lambda / \AA$ & 0,71073 \\
$D_{\text {calc }}, / \mathrm{g} \cdot \mathrm{cm}{ }^{-3}$ & 2,11 \\
$\mu /$ mm $^{-1}$ & 9,642 \\
Total number of reflections & 3425 \\
Number of independent reflections & 3246 \\
Number of reflections with $\left[\mathrm{F}_{0}>4 \sigma\left(\mathrm{F}_{0}\right)\right]$ & 2269 \\
Number of parameters & 254 \\
$(2 \theta)_{\text {max }}{ }^{\circ}$ & 50,14 \\
$R-$ factor $\left(\mathrm{F}_{0}>4 \sigma\left(\mathrm{F}_{0}\right)\right)$ & 0,029 \\
\hline
\end{tabular}

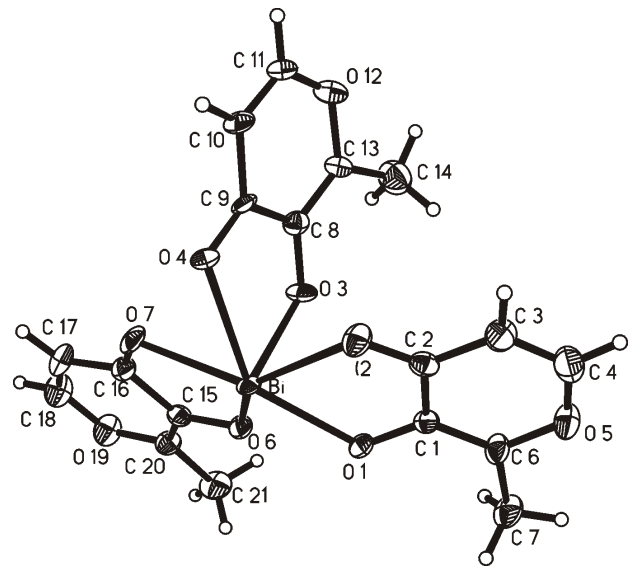

(a)

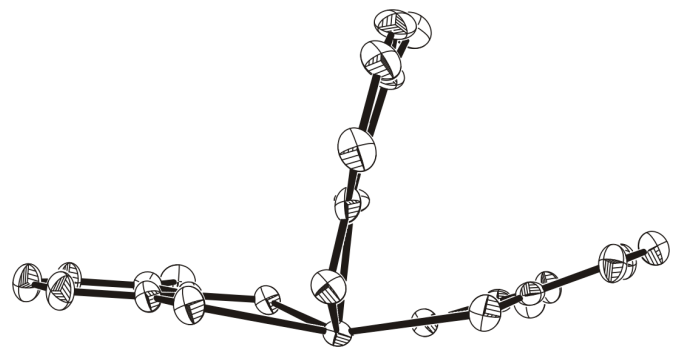

(b)

Figure 2. (a) molecular structure of tris(3-hydroxy-2-methyl-4H-pyran-4-onato)bismuth(III) and (b) conformation. 
Table 4. Bond distances (d) for tris(3-hydroxy-2-methyl-4H-pyran-4-onato)bismuth(III)

\begin{tabular}{cccc}
\hline Bond & $d, \AA$ & Bond & $d, \AA$ \\
\hline Bi-O(1) & $2,276(3)$ & $\mathrm{O}(19)-\mathrm{C}(20)$ & $1,393(7)$ \\
$\mathrm{Bi}-\mathrm{O}(2)$ & $2,481(4)$ & $\mathrm{C}(1)-\mathrm{C}(6)$ & $1,367(7)$ \\
$\mathrm{Bi}-\mathrm{O}(3)$ & $2,150(3)$ & $\mathrm{C}(1)-\mathrm{C}(2)$ & $1,441(7)$ \\
$\mathrm{Bi}-\mathrm{O}(4)$ & $2,487(3)$ & $\mathrm{C}(2)-\mathrm{C}(3)$ & $1,406(8)$ \\
$\mathrm{Bi}-\mathrm{O}(6)$ & $2,275(3)$ & $\mathrm{C}(3)-\mathrm{C}(4)$ & $1,329(9)$ \\
$\mathrm{Bi}-\mathrm{O}(7)$ & $2,447(4)$ & $\mathrm{C}(6)-\mathrm{C}(7)$ & $1,509(8)$ \\
$\mathrm{O}(1)-\mathrm{C}(1)$ & $1,321(6)$ & $\mathrm{C}(8)-\mathrm{C}(13)$ & $1,371(7)$ \\
$\mathrm{O}(2)-\mathrm{C}(2)$ & $1,254(6)$ & $\mathrm{C}(8)-\mathrm{C}(9)$ & $1,452(7)$ \\
$\mathrm{O}(3)-\mathrm{C}(8)$ & $1,318(6)$ & $\mathrm{C}(9)-\mathrm{C}(10)$ & $1,408(7)$ \\
$\mathrm{O}(4)-\mathrm{C}(9)$ & $1,250(7)$ & $\mathrm{C}(10)-\mathrm{C}(11)$ & $1,314(9)$ \\
$\mathrm{O}(5)-\mathrm{C}(4)$ & $1,316(8)$ & $\mathrm{C}(13)-\mathrm{C}(14)$ & $1,486(9)$ \\
$\mathrm{O}(5)-\mathrm{C}(6)$ & $1,353(7)$ & $\mathrm{C}(15)-\mathrm{C}(20)$ & $1,372(7)$ \\
$\mathrm{O}(7)-\mathrm{C}(16)$ & $1,239(7)$ & $\mathrm{C}(15)-\mathrm{C}(16)$ & $1,457(7)$ \\
$\mathrm{O}(6)-\mathrm{C}(15)$ & $1,318(6)$ & $\mathrm{C}(16)-\mathrm{C}(17)$ & $1,422(8)$ \\
$\mathrm{O}(12)-\mathrm{C}(11)$ & $1,345(7)$ & $\mathrm{C}(17)-\mathrm{C}(18)$ & $1,308(9)$ \\
$\mathrm{O}(12)-\mathrm{C}(13)$ & $1,360(7)$ & $\mathrm{C}(20)-\mathrm{C}(21)$ & $1,468(8)$ \\
$\mathrm{O}(19)-\mathrm{C}(18)$ & $1,334(7)$ & & \\
\hline
\end{tabular}

This explains the fact that the bismuth atom, being involved in the additional non-valence interactions, deviates from the base of the pyramid $(0.44 \AA)$ in the direction opposite to apical atom $\mathrm{O} 3$ towards the metal atom of the neighbor molecule. Due to these contacts dimer associates are formed (Figs. 3, 4), while Bi atom becomes nine-coordinated.

Table 5. Angles $(\omega)$ for tris(3-hydroxy-2-methyl-4H-pyran-4-onato)bismuth(III)

\begin{tabular}{cccc}
\hline Angle & $\omega^{o}$ & Angle & ${ }^{o},{ }^{o}$ \\
\hline $\mathrm{O}(3)-\mathrm{Bi}-\mathrm{O}(6)$ & $80,9(1)$ & $\mathrm{C}(3)-\mathrm{C}(2)-\mathrm{C}(1)$ & $115,5(5)$ \\
$\mathrm{O}(3)-\mathrm{Bi}-\mathrm{O}(1)$ & $83,2(1)$ & $\mathrm{C}(4)-\mathrm{C}(3)-\mathrm{C}(2)$ & $121,8(6)$ \\
$\mathrm{O}(6)-\mathrm{Bi}-\mathrm{O}(1)$ & $73,1(1)$ & $\mathrm{O}(5)-\mathrm{C}(4)-\mathrm{C}(3)$ & $122,2(6)$ \\
$\mathrm{O}(3)-\mathrm{Bi}-\mathrm{O}(7)$ & $85,1(1)$ & $\mathrm{O}(5)-\mathrm{C}(6)-\mathrm{C}(1)$ & $122,2(5)$ \\
$\mathrm{O}(6)-\mathrm{Bi}-\mathrm{O}(7)$ & $69,7(1)$ & $\mathrm{O}(5)-\mathrm{C}(6)-\mathrm{C}(7)$ & $112,1(5)$ \\
$\mathrm{O}(1)-\mathrm{Bi}-\mathrm{O}(7)$ & $142,3(1)$ & $\mathrm{C}(1)-\mathrm{C}(6)-\mathrm{C}(7)$ & $125,6(5)$ \\
$\mathrm{O}(3)-\mathrm{Bi}-\mathrm{O}(2)$ & $76,0(1)$ & $\mathrm{O}(3)-\mathrm{C}(8)-\mathrm{C}(13)$ & $120,9(5)$ \\
$\mathrm{O}(6)-\mathrm{Bi}-\mathrm{O}(2)$ & $137,8(1)$ & $\mathrm{O}(3)-\mathrm{C}(8)-\mathrm{C}(9)$ & $120,9(5)$ \\
$\mathrm{O}(1)-\mathrm{Bi}-\mathrm{O}(2)$ & $69,6(1)$ & $\mathrm{C}(13)-\mathrm{C}(8)-\mathrm{C}(9)$ & $118,1(5)$ \\
$\mathrm{O}(7)-\mathrm{Bi}-\mathrm{O}(2)$ & $140,7(1)$ & $\mathrm{O}(4)-\mathrm{C}(9)-\mathrm{C}(10)$ & $124,7(5)$ \\
$\mathrm{O}(3)-\mathrm{Bi}-\mathrm{O}(4)$ & $72,1(1)$ & $\mathrm{O}(4)-\mathrm{C}(9)-\mathrm{C}(8)$ & $119,3(4)$ \\
$\mathrm{O}(6)-\mathrm{Bi}-\mathrm{O}(4)$ & $133,1(1)$ & $\mathrm{C}(10)-\mathrm{C}(9)-\mathrm{C}(8)$ & $116,0(5)$ \\
\hline
\end{tabular}




\begin{tabular}{cccc}
\hline $\mathrm{O}(1)-\mathrm{Bi}-\mathrm{O}(4)$ & $137,4(1)$ & $\mathrm{C}(11)-\mathrm{C}(10)-\mathrm{C}(9)$ & $122,4(6)$ \\
$\mathrm{O}(7)-\mathrm{Bi}-\mathrm{O}(4)$ & $70,4(1)$ & $\mathrm{C}(10)-\mathrm{C}(11)-\mathrm{O}(12)$ & $121,3(5)$ \\
$\mathrm{O}(2)-\mathrm{Bi}-\mathrm{O}(4)$ & $71,1(1)$ & $\mathrm{O}(12)-\mathrm{C}(13)-\mathrm{C}(8)$ & $121,4(5)$ \\
$\mathrm{C}(1)-\mathrm{O}(1)-\mathrm{Bi}$ & $117,4(3)$ & $\mathrm{O}(12)-\mathrm{C}(13)-\mathrm{C}(14)$ & $113,1(5)$ \\
$\mathrm{C}(2)-\mathrm{O}(2)-\mathrm{Bi}$ & $111,9(3)$ & $\mathrm{C}(8)-\mathrm{C}(13)-\mathrm{C}(14)$ & $125,5(5)$ \\
$\mathrm{C}(8)-\mathrm{O}(3)-\mathrm{Bi}$ & $117,2(3)$ & $\mathrm{O}(6)-\mathrm{C}(15)-\mathrm{C}(20)$ & $122,0(5)$ \\
$\mathrm{C}(9)-\mathrm{O}(4)-\mathrm{Bi}$ & $109,4(3)$ & $\mathrm{O}(6)-\mathrm{C}(15)-\mathrm{C}(16)$ & $119,3(4)$ \\
$\mathrm{C}(4)-\mathrm{O}(5)-\mathrm{C}(6)$ & $119,7(5)$ & $\mathrm{C}(20)-\mathrm{C}(15)-\mathrm{C}(16)$ & $118,7(5)$ \\
$\mathrm{C}(16)-\mathrm{O}(7)-\mathrm{Bi}$ & $114,1(3)$ & $\mathrm{O}(7)-\mathrm{C}(16)-\mathrm{C}(17)$ & $124,6(5)$ \\
$\mathrm{C}(15)-\mathrm{O}(6)-\mathrm{Bi}$ & $116,8(3)$ & $\mathrm{O}(7)-\mathrm{C}(16)-\mathrm{C}(15)$ & $119,0(5)$ \\
$\mathrm{C}(11)-\mathrm{O}(12)-\mathrm{C}(13)$ & $120,4(5)$ & $\mathrm{C}(17)-\mathrm{C}(16)-\mathrm{C}(15)$ & $116,4(5)$ \\
$\mathrm{C}(18)-\mathrm{O}(19)-\mathrm{C}(20)$ & $119,1(5)$ & $\mathrm{C}(18)-\mathrm{C}(17)-\mathrm{C}(16)$ & $120,7(6)$ \\
$\mathrm{O}(1)-\mathrm{C}(1)-\mathrm{C}(6)$ & $122,7(5)$ & $\mathrm{C}(17)-\mathrm{C}(18)-\mathrm{O}(19)$ & $124,2(6)$ \\
$\mathrm{O}(1)-\mathrm{C}(1)-\mathrm{C}(2)$ & $119,1(4)$ & $\mathrm{C}(15)-\mathrm{C}(20)-\mathrm{O}(19)$ & $120,7(5)$ \\
$\mathrm{C}(6)-\mathrm{C}(1)-\mathrm{C}(2)$ & $118,2(5)$ & $\mathrm{C}(15)-\mathrm{C}(20)-\mathrm{C}(21)$ & $126,3(5)$ \\
$\mathrm{O}(2)-\mathrm{C}(2)-\mathrm{C}(3)$ & $124,1(5)$ & $\mathrm{O}(19)-\mathrm{C}(20)-\mathrm{C}(21)$ & $113,(5)$ \\
$\mathrm{O}(2)-\mathrm{C}(2)-\mathrm{C}(1)$ & $120,4(5)$ & & \\
\hline
\end{tabular}

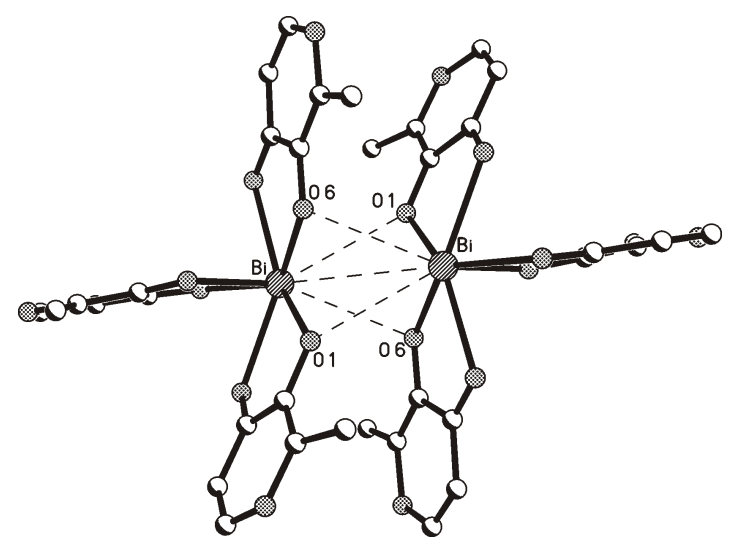

Figure 3. Dimer associate of tris(3-hydroxy-2-methyl-4H-pyran-4-onato)bismuth(III).

Particular emphasis is placed upon the extension of the $\mathrm{C}-\mathrm{O}$ bonds, which are in cis-position with respect to methyl substitute: the $\mathrm{O} 1-\mathrm{C} 1, \mathrm{O} 3-\mathrm{C} 8$ and $\mathrm{O} 6-\mathrm{C} 15$ bond are longer than the $\mathrm{O} 2-\mathrm{C} 2, \mathrm{O} 4-\mathrm{C} 9, \mathrm{O} 7-\mathrm{C} 16$ bond by $0.07 \AA$ that points to the absence of delocalization of the $\mathrm{C}-\mathrm{O}$ bonds in metal rings.

Metal rings deviates insignificantly from plane conformation: dihedral angles between $\mathrm{BiO} 1 \mathrm{O} 2 / \mathrm{O} 1 \mathrm{C} 1 \mathrm{C} 2 \mathrm{O} 2, \mathrm{BiO} 3 \mathrm{O} 4 / \mathrm{O} 3 \mathrm{C} 8 \mathrm{C} 9 \mathrm{O} 4, \mathrm{BiO} 6 \mathrm{O} 7 / \mathrm{O} 6 \mathrm{C} 15 \mathrm{C} 16 \mathrm{O} 7$ planes are $169.2,171.1$ and $170.8^{\circ}$, respectively. 


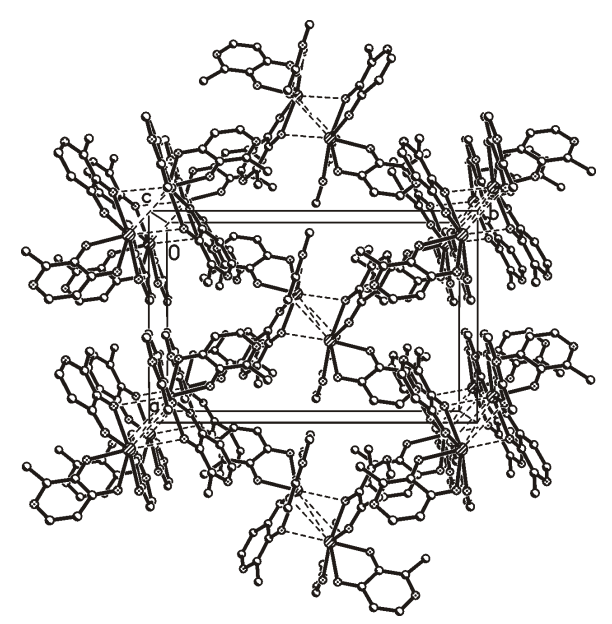

Figure 4. Packing diagram in the until cell of tris(3-hydroxy-2-methyl-4H-pyran-4onato)bismuth(III).

In this paper, we report the synthesis and characterisation of previously unknown tris(3hydroxy-2-methyl-4H-pyran-4-onato)bismuth(III), a rare example of the complexes of hexacoordinated bismuth(III) with stereoactive lone pair. In crystal packing, molecules of the complex are dimers due to the $\mathrm{Bi} . . . \mathrm{Bi}$ and $\mathrm{Bi}$... O contacts.

\section{Experimental Section}

General Procedures. Maltol was extracted from needles of Abies sibirica Ledeb. and purified according to the published procedure. ${ }^{2}$ The other reagents employed were reagent-grade.

IR spectra were recorded on a Specord 75 IR $\left(4000-800 \mathrm{~cm}^{-1}\right)$ and on Specord M-82 (800 $200 \mathrm{~cm}^{-1}$ ) instruments. UV spectra were recorded on Specord UV/VIS spectrophotometer. ${ }^{1} \mathrm{H}$ NMR and ${ }^{13} \mathrm{C}$ NMR spectra were recorded on the Bruker DPX-400 and AV-400 at $400.13 \mathrm{MHz}$ and $101.61 \mathrm{MHz}$, respectively, using HMDS as an internal standard. ${ }^{13} \mathrm{C}$ NMR spectra were recorded under complete decoupling from protons as well as without decoupling. Spectral assignment in the ${ }^{13} \mathrm{C}$ NMR spectrum was carried out based on the $2 \mathrm{D}$ correlation diagrams HMBC. The X-ray diffractions studies were carried out on Kuma Diffraction KM-4 diffractometer at room temperature $\left(\omega / 2 \theta\right.$-scan mode, $\mathrm{Mo}_{\mathrm{K} \alpha}$ radiation, graphite monochromator). The crystal structure was solved by direct methods followed by Fourier syntheses with SHELXS-97 ${ }^{36}$ and refined using anisotropic full-matrix least-squares approximation for all nonhydrogen atoms using SHELXL-97 ${ }^{36}$. Hydrogen atoms were placed geometrically. An absorption correction was applied ${ }^{37}, \mathrm{~T}_{\min }=0.294, \mathrm{~T}_{\max }=0.736$. Crystal data collection and details of the structure determination are summarized in Table 3. 


\section{General procedure for the preparation of tris(3-hydroxy-2-methyl-4H-pyran-4- onato)bismuth(III)}

The aqueous solution of maltol (3.78 $\mathrm{g}, 0.03 \mathrm{~mol}$ in $150 \mathrm{ml}$ of water) was added to the stirred suspension of $\mathrm{Bi}\left(\mathrm{NO}_{3}\right)_{3} \cdot 5 \mathrm{H}_{2} \mathrm{O}(5.84 \mathrm{~g}, 0.01 \mathrm{~mol}$ in $50 \mathrm{ml}$ of water). Then the aqueous $2 \mathrm{~N}$ solution of $\mathrm{NaOH}$ was added dropwise to the reaction mixture under constant stirring until $\mathrm{pH}=$ 7.5. The mixture was stirred for $20 \mathrm{~min}$, and then allowed to stand for $12 \mathrm{~h}$ at $5-7^{\circ} \mathrm{C}$. The paleyellowish residue was filtered off, washed with water and alcohol and dried under reduced pressure. Yield of the product was $5.43 \mathrm{~g}(93 \%)$. Elemental analysis (\%): calcd. for $\mathrm{C}_{18} \mathrm{H}_{15} \mathrm{BiO}_{9}$ : C 37.0; H 2.57; Bi 35.79; found: C 37.67; H 2.86; Bi 35.98. The monocrystals ( $m p 245{ }^{\circ} \mathrm{C}$ ) were grown from saturated aqueous solution at $90^{\circ} \mathrm{C}$ by slow cooling and evaporation of the solvent.

\section{Supplementary Information Available}

CCDC 631348 contains the supplementary crystallographic data for this paper. These data can be obtained free of charge via www.ccdc.cam.ac.uk./conts/retrieving.html (or from Cambridge Crystallographic Data Centre (CCDC, 12 Union Road, Cambridge CB2 1EZ, UK; fax: (+44)1223-336-033; or deposit@ccdc.cam.ac.uk).

\section{Acknowledgements}

The work has been performed under financial support of Russian Foundation for Basic Research (Grants No. 05-03-97208, No. 05-04-97269) and Siberian Branch of the Russian Academy of Sciences (Complex Integration Project N 13).

\section{References and Notes}

1. Medvedeva, S. A. PhD Thesis, Institute of Organic Chemistry (USSR), 1973.

2. Medvedeva, S. A.; Antipova, I. A.; Mukha, S. A.; Tyukavkina, N. A.; Patent RU 2171805, 2001.

3. Aoyagi, N.; Kimura, R.; Murata, T. Chem. Farm. Bull. 1974, 22, 1008.

4. Takaishi, K. Phytochemistry 1971, 10, 3302.

5. Yasue, M.; Kawamura, N.; Ishibashi, K. Yakugaku Zasshi (J. Pharm. Soc. Jpn.). 1968, 88, 390; Chem. Abstr. 1968, 69, 97026y.

6. Ahmed, S. I.; Burges, J.; Fawsett, J.; Parsons, S. A.; Russell, D. R.; Laurie, S. H. Polyhedron 2000, 19, 129.

7. Vorbrodt, W.; Trowbridge, R. S.; Dobrogowska, D. H. Histochem. J. 1994, 26, 119. 
8. Bertholf, R. L.; Herman, M. M.; Savory, J.; Carpenter, R. M.; Sturgill, B. C.; Katsetos, C. D.; Vandenberg, S. R.; Wills, M. R. Toxicol. Appl. Pharmacol. 1989, 98, 58.

9. Reffitt, D. M.; Burden, T. J.;Seed, P. T.;Wood; R. J.; Thompson, R. P. H.; Powell, J. J. Ann. Clin. Biochem. 2000, 37, 457.

10. Harvey, R. S. J.; Reffitt, D. M.; Doig, L. A.; Meenan, J.; Ellis, R. D.; Thompson, R. P. H.; Powell, J. J. Aliment. Pharmacol. Ther. 1998, 12, 845.

11. Burgess, J. Trans. Met. Chem. 1993, 18, 439 .

12. Yuen, V. G.; Caravan, P.; Gelmini, L. J. Inorg. Biochem. 1997, 68, 109.

13. Abros, W.; Dziga, D.; Grybos, R.; Kordowiak, A. M. Pathol. Res. Pract. 2000, 196, 561.

14. Coordination compounds of metals in medicine, Kriss, E. E.; Volchenkov, I. I.; Grigoriev, A. S. et al., Eds., Naukova Dumka: Kiev, 1986; p 216

15. Mashkovskii, D. Medicinal drugs, Novaya volna, Moscow, 2000, p. 539.

16. Suh, D.-Y.; Han, Y. N. ; Yong, B. H. Arch. Pharmacal Res. 1996, 19, 112.

17. Babenkova, V.; Teselkin, Yu. O.; Medvedeva, S. A.; Tyukavkina, N. A.; Kolesnik, Yu. A.; Rebrov, L. B.; Bykov, V. A.; Mukha, S. A.; Antipova, I. A. Problems of Biological, Medicinal and Pharmaceutical Chemistry. 2001, N 4, 22.

18. Murakami, K.; Ito, M.; Tanemura, Y.; Yoshino, M. Biomed. Res. 2001, 22, 183.

19. Galdecki, Z.; Glowka, M. L.; Golinski, B. Acta Cryst. 1976. B32, 2319.

20. Snow, M. R.; Tiekink, E. R. T. Austral. J. Chem. 1987, 40, 743.

21. Burgess, J.; Fawcett, J.; Parsons, S. A.; Russell, D. R. Acta Cryst. 1994. C50. 1911.

22. Wells, F. In Structural Inorganic Chemistry, $5^{\text {th }}$ Edn. Clarendon Press: Oxford, 1984.

23. Antipova, I. A.; Mukha, S. A.; Medvedeva, S. A. Rus. Chem. Bull. 2004, 4, 744.

24. Antipova, I. A.; Mukha, S. A.; Medvedeva, S. A. Chemisry for Sustainable Development 2005, 13, N 3, 377.

25. Mukha, S. A.; Chipanina, N. N.; Sterkhova, I A.; Aksamentova, T. N.; Medvedeva, S. A.; Turchaninov, V. K. Chem. Heterocycl. Comp. 2006, 473, 1635.

26. Morita, H.; Shimomura, S.; Kawaguchi, S. Bull. Chem. Soc. Jpn. 1976. 49, 2461.

27. Gerard, C. Bull. Soc. Chim. France. 1979, 11-12, 451.

28. Mukha, S. A.; Antipova, I. A.; Medvedeva, S. A.; Saraev, V. V.; Larina, L. A.; Cyrenzhapov, A. V.; Sukhov, B. G. Chemisry for Sustainable Development 2007, 15, N 4, 457.

29. Finnegan, M. M.; Rettig, S. J.; Orvig, C. J. Am. Chem. Soc. 1986, 10, 5033.

30. Achmet, M. T.; Frampton, C. S.; Silver, J. J. Chem. Soc., Dalton Trans. 1988, 1159.

31. Lewis, J. A.; Puerta, D. T.; Cohen, S. M. Inorg. Chem. 2003, 42, 7455.

32. Gillespie, R. J.; Nyholm, R. S. Quart. Rev. 1957, 11, 339.

33. Kurteva, V. B.; Lyapova, M. J.; Pojarlieff, I. G. ARKIVOC 2006, (ii), 91.

34. Chandrasekhar, S. ARKIVOC 2005, (xiii), 37.

35. Batsanov, S. S. Rus. J. Inorg. Chem. 1991, 36, 3015.

36. Sheldrick, G. M. SHELXS-97, SHELXL-97, Programs for Crystal Structure Determination and Refinement, Göttingen University, Göttingen (Germany), 1997.

37. North, C. T.; Phillips, D. C.; Mathews, F. S. Acta Cryst. 1968, A24, 351. 